Anales de Historia del Arte

ISSN: 0214-6452

http://dx.doi.org/10.5209/anha.66049

\title{
PRESENTACIÓN
}

\section{Repensar el museo}

Eva Fernández del Campo

Orcid 0000-0002-4125-0191 Directora de Anales de Historia del Arte

Conmemoramos el bicentenario del Museo del Prado con este número de Anales de Historia del Arte que propone repensar el museo, abrir un foro a los investigadores no solo sobre el pasado, presente y futuro de la pinacoteca, sino sobre el museo en general, una institución estrechamente ligada a la docencia que desarrolla el Departamento de Historia del Arte, y que está siempre presente en nuestro horizonte investigador. Como autor invitado en este número tenemos a Uwe Fleckner, profesor de Historia del Arte en la Universidad de Hamburgo y director de la Warburg-Haus, que con su texto sobre la utilización del cuerpo humano como tema de exhibición, pone sobre la mesa algunas de las cuestiones fundamentales en el debate actual haciéndonos, una vez más, cuestionarnos la finalidad y objetivos de los museos.

Hemos incluido también dos ensayos de dos de nuestros mas eminentes profesores y queridos compañeros, que han fallecido recientemente dejando un copioso trabajo sobre el tema que tratamos. Dos textos que ofrecen perspectivas antagónicas y al mismo tiempo complementarias sobre el museo y que nos abren un fértil campo para el debate científico sobre el sentido de esta institución pública fundamental en nuestra vida. Mientras el museo, que para algunos constituye, como nos recuerda Francisco Calvo Serraller en el artículo que hemos reeditado aquí, uno de los grandes logros de la Revolución Francesa para la democratización del arte, para otros, como Ángel González es, sin embargo, un lugar no demasiado adecuado para la que debía ser su finalidad última: el disfrute.

Decía Paul Valery que los museos tienen algo de cárceles, que son lugares autoritarios, donde nada más entrar se tiene el sentimiento de coerción, donde reina una confusión fría y cuya finalidad no está siempre clara:

“ ¿He venido a instruirme, o a buscar algo que me encante, o bien a cumplir con un deber y satisfacer las apariencias? ¿O no podría ser incluso un ejercicio de un género particular este paseo tan pintoresco, al que una belleza estorba cada paso y a cada instante desvían a diestro y siniestro obras maestras entre las que hay que conducirse como un borracho entre bares?"1

Entre el museo como lugar de conocimiento, como centro de conservación y como emplazamiento para el deleite discurren muchas disputas. También nos lo re-

1 Valery, Paul (2005), Piezas sobre arte, Madrid, Visor, p. 106. 
cuerda la obra de Muntadas que reproducimos en la portada de este número de la revista: el cartel colocado en la puerta de Cittadelarte que reza «Atención: la percepción exige compromiso» y que empuja al público a adoptar una actitud activa y comprometida respecto a lo que va a ver en el interior de las distintas instituciones museísticas donde el artista ha hecho esta intervención.

Hemos conversado con Miguel Zugaza, ex director del Museo del Prado y persona muy vinculada a nuestro departamento, sobre la función del museo y su relación con la universidad. Jesusa Vega, catedrática de historia del Arte en la UAM y ex directora del Museo Lázaro Galdiano, alerta en el artículo que publica en este número tanto sobre la realidad irreversible de que la disciplina de base del museo de arte ya no sea la Historia del Arte, como sobre la progresiva mercantilización de la institución, proponiendo para el siglo XXI que museo y academia vuelvan a construir espacios de diálogo, basados en el respeto mutuo, al mismo tiempo que nos recuerda cual es la definición de museo para el ICOM:

«un museo es una institución sin fines lucrativos, permanente, al servicio de la sociedad y su desarrollo, abierta al público, que adquiere, conserva, investiga, comunica y expone el patrimonio material e inmaterial de la humanidad y su medio ambiente con fines de educación, estudio y recreo».

Presentamos también en este volumen varios estudios de casos concretos de museos y colecciones: los conventos de las madres dominicas de Córdoba, la colección de tapices del Palacio de Linares, el Palacio Episcopal de Segovia, la colección de Arte Contemporáneo de la Universidad del País Vasco y el Museo Julio Romero de Torres de Córdoba. Pero los nuevos retos sociales y los nuevos medios exigen, así mismo, repensar el museo desde perspectivas hasta ahora inéditas, así lo ponen de manifiesto el texto de Julio Pérez Manzanares sobre el apropiacionismo y la resignificación de algunas obras del Museo del Prado para legitimar relatos vinculados con las cuestiones de género y la teoría queer, el ensayo de Valeria Calporesi, que reflexiona sobre la inclusión en el museo de películas destinadas originalmente al consumo comercial y el artículo de Francisco Falero sobre el turismo cultural y su impacto en el patrimonio.

Se habla también en este volumen, cómo no, sobre el papel de los coleccionistas y de los artistas en este contexto. Sobre las propuestas de estos últimos trata el texto de Beatriz Cordero que, de manera muy sintomática, comienza con una cita del Fausto que dice: «Lo que llamáis espíritu de los tiempos es en realidad el espíritu particular de aquellos hombres en los que los tiempos se reflejan». ¿Pero quienes serían esos hombres para el museo? Ángel González plantea esa pregunta de manera muy pertinente ¿A quién le sirve el museo de casa? Su respuesta es que los ricos se están apropiando de los museos de titulación pública desvirtuando una institución a la que le correspondía negociar los usos comunes del arte en una sociedad desarticulada. Entre el museo inimaginable de Georges Duthuit y el museo imaginario de André Malraux, esta institución amenaza con convertirse efectivamente en lugar de exposición de los poderosos, pero también en un parque temático destinado al entretenimiento de masas. Nuestra época asiste igualmente a la transformación del museo en un lugar para la exposición de otras cosas que no son lo que hemos considerado antes obras de arte: desde el cuerpo humano a las caprichosas colecciones de algunos 
adinerados, pasando por el despliegue de imágenes que sustituyen a los originales, o a la cesión del protagonismo de los mismos por eso que ahora se llama la «economía del evento» o los procesos de mediación. Todo ello en aras, ciertamente, de la rentabilidad política que se espera de él, desvirtuando así su sentido y haciendo que el papel de la academia y de la producción científica se vean supeditadas a intereses espúreos.

Finalmente el museo ha llegado, incluso, a dejar de ejercer su función de contenedor del arte para exhibirse a sí mismo; Selina Blasco habla en su texto de la invisibilidad del arte y la visibilidad del espacio expositivo y analiza prácticas artísticas que exponen un museo literalmente vacío o que impide y obstruye el acceso a las obras. Entre los museos vacíos y el arte en la calle, las tradicionales definiciones de museo se desdibujan en un horizonte incierto para el museo del siglo XXI y nos ofrecen un campo de debate en el que ese lugar controvertido, que ejercía tanto de casa para las musas como de «tanatorio de embalsamamiento» para las obras de $\operatorname{arte}^{2}$, ese lugar en el que, como nos recuerda Ángel González, el tiempo transcurre de un modo distinto al habitual y que puede pasar de ser desde una templo del conocimiento, a un lugar para el orden de la Historia y para la preservación de la memoria colectiva hasta un "antro" o un lugar inverosímil y ensimismado con el paso del tiempo, sigue constituyendo uno de los ejes de la investigación de los historiadores del arte.

${ }^{2}$ Cioran, Emile (2004), Desgarradura, Barcelona, Tusquets, p. 32. 